1-3.875a Sewpaul $V$

\title{
EMANCIPATORY CITIZENSHIP EDUCATION IN ACTION: DISCOURSE ETHICS AND DECONSTRUCTION (PART 1)
}

\author{
Prof Vishanthie Sewpaul, professor, Centre for Social Work, University of KwaZulu Natal, \\ Durban
}

The social circumstance needs changing, for sure, but it is still the classroom that can determine the impact of education ... and that cannot wait until the whole world is straight.

(Wheeler cited in Robinson \& Angelis, 1989: 164)

\begin{abstract}
This paper elucidates the importance of emancipatory education to social work education and training, identifies the objectives and underlying epistemologies of a course on Human Behaviour and the Social Environment, and emphasises the importance of negotiating relationships for the creation of a participatory and emancipatory approach to education. It reflects the application of Habermas's (1996) theory of communicative action and discourse ethics to complex issues including HIVIAIDS and the relationship between race, class and gender and the relationship of these to issues of power, privilege, status and access to resources in the South African context. The incorporation of creative, experiential and empowerment-based teaching/learning strategies are central to the development of critical consciousness in students, and for facilitating effective and meaningful citizen participation among students. The paper also highlights the potentially damaging, albeit unintended, consequences of such teaching strategies.
\end{abstract}

\section{INTRODUCTION}

The above quotation is open to contention, raising the age-old dilemma about where we locate our sites of intervention. Some may argue that we should, indeed, seek the utopian ideal and attempt to change the world in one fell swoop. There is clearly a need for radical structural changes at the local, national and international levels. However, the most profound sphere of influence for the educator remains the classroom. Students are a powerful medium through which service users may be empowered. At the most basic level the purpose of social work education and training is to equip students with the values, knowledge and skills to effectively and holistically assess and intervene at multiple system levels and with different sizes of client systems. This simple statement belies the kinds of challenges and difficulties involved in getting students to effectively use basic knowledge and skills and to reflect the core values of social work. The difficulty becomes even more challenging when one considers the range of fields of practice, the sheer complexity of human behaviour, the increasing call for understanding of diversity in all its facets, and responding to the needs of people in a rapidly globalising world. In the face of such challenges it is unfortunate that the formal lecture is seen to be efficient and economical, and that it prevails as the major mode of instruction in tertiary education (Bernstein \& Gray, 1989).

If social work education and training have to become and remain responsive to the needs of service users in our increasingly complex world, the modus operandi of educators and the learning/teaching environment of the classroom have to be transformed. Social work educators need to incorporate more creative, experiential and empowerment-based teaching/learning strategies and the development of critical consciousness in students. Students need to be prepared for effective and meaningful citizenship participation. Louw and Annecke (1989:124) defined 
experiential learning as "...the process of learning by and through experience in the real world as well as a method of teaching and learning in the classroom situation." Students' experiences are, in themselves, inadequate as the basis of learning. Experience must serve as the springboard for reflection and deconstruction, as the prerequisite for learning is reflection. Given that common sense or life experience may sometimes serve to conceal rather than reveal reality (Gramsci, 1971), experience is what one may have to "halt, check, negate, in order to get knowledge" (Aitchison \& Graham, 1989:17).

This paper is written as a two-part series. Part One describes the use of Habermas's (1996) theory of communicative action, including discourse ethics and argumentation to facilitate reflexive learning. It focuses on the work done during the first term of the first semester with students taking a course in Human Behaviour and the Social Environment at the first-year undergraduate level at the University of Natal, Durban. This is preceded by a discussion on social work and emancipatory citizenship education. Part Two describes the use of other student-centred creative teaching/learning strategies to demonstrate a holistic view of the life course used during the second term of the first semester. Parts One and Two should ideally be read in conjunction with each other. Apart from the potential pragmatic utility in sharing both content and process with colleagues, it is important that academics theorise around pedagogical practice. Much of the literature on emancipatory citizenship education describes what educators ought to do (Edwards \& Fogelman, 1993; Giroux, 1983, 1994, 1997; Lynch, 1992; Robinson \& Angelis, 1989). This paper describes the application of the principles and strategies of emancipatory education.

\section{SOCIAL WORK AND EMANCIPATORY CITIZENSHIP EDUCATION}

The concept of citizenship remains ambiguous and fluid. It ranges from equation with nationality and membership of the nation state, implications of adherence to a nation's rule of law and national citizenship rights and obligations (Heywood, 1999) to citizenship within the global context of international human rights, international law and commerce, transnational transport and communication and environmental concerns (Lynch, 1992). At the most basic level citizenship at the national level represents a "relationship between the individual and the state, in which the two are bound together by reciprocal rights and obligations" (Heywood, 1999:207). However, the nature of this relationship is open to dispute. Citizenship may be used to refer to one's legal status, to one's identity depicting elements of loyalty and belonging, and to the complexity of defining national identification vis-à-vis other identities such as ethnicity, religion and class affiliation. According to Heywood (1999), the most contentious issue relates to the nature of citizenship rights and obligations, and the balance between the two.

Despite the ambiguities surrounding the concept of citizenship, the goals of citizenship education have been fairly widely described in the literature, with a degree of consensus amongst authors (Lynch, 1992; Edwards and Fogelman, 1993; Dominelli, 1996; Giroux, 1983, 1994, 1997; Sewpaul, 2003). Giroux (1983, 1994, 1997), Dominelli (1996) and Sewpaul (2003) called for a radical and emancipatory pedagogy to underscore citizenship education. Emancipatory citizenship education, according to Giroux (1997:225), provides scope for students to "...extend their understandings of themselves and the global contexts in which they live ... (and it) affirms the importance of offering students a language that allows them to reconstruct their moral and political energies in the service of creating a more just and equitable order, one that undermines relations of hierarchy and domination." A critical reflection of one's social and political realities and the capacity to develop action strategies consequent upon these reflections is central to emancipatory pedagogy and to social work education and practice. 
Post-apartheid South Africa has seen an increasing interest, within the broader educational sphere, in citizenship education, with an emphasis on the acquisition of life skills, the development of positive attitudes and values, problem solving, reflexivity, decision making and education for effective social and political participation. According to Edwards and Fogelman (1993), citizenship education is concerned with: decision making; establishing and developing interpersonal relationships; exercising rights and responsibilities; and participating in and contributing to the community. While acknowledging group affiliation at the local and national levels, Lynch (1992) called for a greater emphasis on an international paradigm of citizenship, and for the internationalisation of curricula in the classroom. Writing within the context of social work, Dominelli (1996) similarly argued that social work educators have a key role to play in adopting emancipatory approaches and in internationalising the social work curricula in order to counteract the forces of globalisation, industrialism and militarism. Lynch (1992:17) contended that the global sphere is "framed by a perception of social and political anomie in industrialized societies, caused by disillusion with the formalism of the democratic process, the ideological failure of materialism to adequately legitimate the human condition, major urban crises, drug dependency, child and female abuse, family breakdown, corruption, crime and violence, catastrophic environmental degradation and pollution, as well as a groundswell of interethnic strife and bigotry". He cited these as arguments for a citizenship education that demand new approaches to human social and economic development. To be truly effective social work education needs to mediate between the imperatives of globalisation and international educational trends, on the one hand, and locally specific historical, economic, socio-cultural and ideological realities on the other.

Social work, as a human service discipline, has as its major aim the pursuit of human rights and social justice, and the creation of enabling environments for people to recognise their potential and worth. Thus social work educators have an ethical obligation to prepare their students for effective citizenship participation at local, regional, national and international levels. This calls for nontraditional modes of teaching that move beyond the didactic lecture and transmission of knowledge. More radically oriented experiential modes of teaching and learning that facilitate the working together experiences of students (Bernstein and Gray, 1989), and ensuring that the student remains the cite of politicisation and critical reflection (Giroux, 1983, 1994; Sewpaul 2003), have to become institutionalised. This is especially so in the South African context, which still carries the legacy of apartheid, based on stratification and differentiation, which permeated every aspect of life. The separation of people along racial lines, although no longer institutionalised, is still a major feature of South African society. In South Africa during the apartheid years white and black, as binary opposites, were used as a primary signifier of difference. However, the discourse on difference has increasingly included other signifiers such as gender, culture, ethnicity, sexual orientation and socio-economic status. Literature confirms that race, class and gender intersect in powerful ways to influence access to status, power, privilege and resources (Dominelli 2002; Giroux, 1994, 1997; Sewpaul, 1994, 2003). However, class and gender are not in themselves the answers to cultural studies. The more challenging concern is the kinds of difference that people acknowledge and become engaged with (Grossberg cited in Giroux, 1994). The classroom and the university are microcosms of broader society, with the archetypal representations of race, gender and ethnicity manifesting in complex and powerful ways in these contexts, with students reflecting varying degrees of willingness to engage actively with these sensitive issues.

An observation of the utilisation of space in the classroom and across the University of Natal bears testimony to the racial and ethnic divisions that exist. Students, more often than not, tend to remain within their own racial and ethnic groupings and attempts to regroup students in the classroom along non-racial lines sometimes prove difficult. The manifestation outside of the classroom is 
such that a certain part of the university has been nicknamed "Little Mecca" on account of it being dominated by Muslim students. In South Africa the consequences of the Group Areas Act, which enforced a geographic separation of people according to race (the majority of people remain within the previously racially designated areas to date), mean that the majority of students enter university with little or no prior meaningful interaction across race. The challenge is for educators to confront barriers to appreciating and working with diversity, and to get students to appreciate their potential contribution to the enhancement of human well-being. There is a clear call in the literature (Giroux, 1983, 1994, 1997; Lynch, 1992; Freire, 1970, 1972, 1973; Gramsci, 1988, 1971, 1977; Sewpaul, 2003) for the development of citizenship education through emancipatory pedagogical strategies that address issues of power and hegemony, human rights and social responsibility at local, national and international levels. Educators need to draw the links between the classroom and broader social, political and economic realities and struggles.

\section{CITIZENSHIP EDUCATION IN ACTION}

\section{Course objectives and underlying epistemology}

The explicitly stated objectives of the Human Behaviour and the Social Environment course as far as content is concerned include:

- The need to select, integrate and use multidisciplinary knowledge of behaviour in the South African context;

- Understanding of the biological sources of human behaviour;

- Understanding of the psychological dimension of human behaviour;

- Understanding the impact of socio-structural factors on human development and behaviour;

- Understanding of the impact of culture on human development and behaviour;

- Holistic bio-psychosocial and spiritual understanding of the life phases from infancy to old age and death, with an emphasis on life tasks, expectations, crises and events as defined by individual and family developmental conceptual frameworks; and

- An understanding of the powerful intersection of race, class and gender and how these factors interact to influence access to power, privilege, status and resources in the South African context.

Given that HIV/AIDS is one of the most disturbing problems facing South African society, it is embedded as a central theme across the course. From 1990 to 2001 the HIV prevalence levels at public antenatal clinics in South Africa increased from $0.8 \%$ to $24.8 \%$ (Department of Health, $2000 \&$ 2001), with an estimated 5 million people living with HIV/AIDS, and 70000 children born HIV+ every year. KwaZulu Natal has a far higher prevalence rate of $32.5 \%$ compared to the national average. Those in the 15-29 year age group are most vulnerable to infection, with women being at higher risk compared with men. In view of this, students are viewed as both service users and potential service providers. One basic reality informs this approach: students need to protect themselves against HIV/AIDS if they are to remain alive to be of any use to service users! This is discussed in more detail later.

To facilitate a holistic orientation, the following epistemological frameworks are introduced at the beginning level for first-year students, as reflected in the draft Global Qualifying Standards 
(Sewpaul and Jones, 2004; also available on the following website: http://www.iassw.soton.ac.uk) document:

- An acknowledgement and recognition of the dignity, worth and uniqueness of all human beings;

- A recognition and appreciation of people as biological, psychological and social beings;

- Knowledge and understanding of the inter-connectedness that exists within and across all systems at micro, meso and macro levels;

- Understanding of the impact of structural sources of marginalisation, exclusion and oppression and an appreciation of the need to work toward changes at structural and policy levels;

- Knowledge of the need to work in a wide range of contexts, with different sizes of client populations across all system levels;

- Problem-solving and anticipatory socialisation though an understanding of the normative developmental life cycle, and expected life tasks and crises in relation to age-related influences;

- The assumption, identification and recognition of the strengths and potential of all human beings;

- An appreciation of, and respect for, diversity in relation to race, culture, religion, ethnicity, linguistic origin, gender, sexual orientation and differential abilities.

Apart from the content objectives, the following are the embedded core objectives, which can only be learnt experientially and not taught via the didactic mode:

- The development of self-awareness and an enquiring and critical mind;

- The capacity to make sense/meaning of the world;

- The capacity to engage in reflective discussion and debate;

- The capacity to work independently and as a member of a team;

- The development of a sense of social responsibility;

- A critical examination of self in relation to prejudice, discrimination and ethnocentricism;

- An appreciation of diversity in all its facets;

- Appreciation of the value of ethical behaviour;

- An appreciation of democratic principles, including acceptance of different views and opinions; and

- Developing a spirit of community service.

\section{Negotiating relationships: Creating a climate for participatory education}

Thirty-nine hours of formal lecture time and fifty-two hours of skills training or practice time are allocated to the module, which is taught at the first-year level during the first semester of university. Thus, the majority of the students entering the module tend to be young and recently out of high school. While the module was initially open only to students registered for the 
Bachelor of Social Work degree, it has opened to include any student on campus. It has attracted students from nursing, psychology, education, law, music and community development. The module is compulsory for all students taking the integrated Social Work and the integrated Psychology programmes.

All too often educators are preoccupied with achieving content objectives, with process and the other embedded objectives being compromised. My personal philosophy in teaching is "less is more". Rather than ensure that every single bit of content is taught, I would rather that we do a little less and that students interact thoroughly with the material at hand. It is vital that the power structures within the classroom are acknowledged and dealt with. During the first lecture period students are asked: "What can I expect of you as students?" and their responses are listed on a board. Alongside this we draw up a list in response to the question: "What can you expect of me as a lecturer?" This simple exercise helps students to understand the mutuality of responsibility for teaching and learning. Robinson and Angelis (1989) contend that creating an environment of trust and debate and that negotiation of responsibilities of educators and students are the basis for critical reflection.

Students are then asked about the least useful teaching experiences that they have had, which are also listed on the board. Typical responses include non-participation, not being respected as students and didactic modes of teaching. We then list the most empowering or useful learning experiences that they have had. These include responses such as being involved, the lecturer showing enthusiasm about his/her work, being valued as students, and openness to discussion, debate and criticism. We thus conclude that I cannot do my work well, and that I would not be able to meet their learning needs, without their involvement and participation. While I affirm the importance of a non-hierarchical, open and democratic teaching/learning environment, I do acknowledge the inherent power imbalances in the lecturer-student relationship. The legitimacy of my role as educator with regard to ensuring class attendance (while attendance at lectures is at the discretion of students, attendance at practice sessions is compulsory), setting and grading of class assignments and examinations, and evaluation of practice sessions are addressed. Students are also informed about the possible abuse of the lecturer's authority, their rights should this happen, and what routes they may follow should they have concerns or complaints about the lecturer. The relationship between the educator's authority and student responsibility is an important issue in any learning relationship; generally the greater the authority exerted by the educator, the less the responsibility and freedom of the student (Saddington, 1989).

Students are briefed about the overall objectives of the course and are invited to make suggestions and add to the objectives. They are also made aware that the major term assignment is contained in the course outline and are reminded that there is very good reason for my giving them nine weeks to complete it. Given the contemporary situation in South Africa in respect of HIV/AIDS the following assignment was set for 2002: Write an assignment on the biological, psychological, socio-structural and cultural components of HIV/AIDS in the South African context. Include in your assignment a critical examination of the South African Government's response to HIV/AIDS, especially with regard to the provision of anti-retroviral treatment for persons with HIV/AIDS. This may appear to be a tall order for first-year students, but my experience is that students do try to rise to the standards set by the lecturer. What is vital is that we build in the necessary support and structure for students to feel safe and to explore different ways of accessing and presenting their material. 


\section{THEORY AND PRACTICE: PARTICIPATORY LEARNING, DISCOURSE ETHICS AND DECONSTRUCTION}

The course is designed to allow for consistent interaction between theory and practice, with an emphasis on both process and content. The semester is divided into about two equal terms. The first term is dedicated to the integration of theory and practice in respect of the multiple dimensions of human behaviour, underscored predominantly by the eco-systemic and the holistic bio-psychosocial perspectives. The following are some examples of how the theory and practice were integrated.

During the formal "lecture" periods students were introduced, through the use of practical examples, to the eco-systemic perspective and key concepts such as: person-in-situation gestalt, systems, chrono-system, sub-systems and supra-systems and related systems' concepts such as homeostasis, equilibrium, equifinality, boundaries, exchange and network. In the practice sessions students were divided into small groups. One of the first tasks that they were required to do was draw a time-line (reflecting the chrono-system) and all the people and events in their lives that influenced their development from birth until the present. Students are also asked to chart their own genograms, thus reflecting the family as a system, the possible homeostatic mechanisms in their families, what might produce disequilibrium, the types of boundaries that they were able to identify, and so on. The concepts of boundaries, exchange and network were more fully explored by getting the students to draw their eco-maps through which they were able to identify those systems at meso and macro levels that impacted on individual and family development and functioning.

On completing each of the exercises the students chose what they wanted to share with the group and with the wider class. Such exercises facilitate the development of self-awareness and the development of awareness of self in relation to broader society, which are central goals of both social work and emancipatory education. They also enable students to locate themselves within their historical, socio-structural and cultural spaces, which are considered to be the starting point of critical elaboration (Gramsci, 1997). Giroux (1997:159) argued that an examination of the historical and social constructs of our lives "helps to reterritorialize and rewrite the complex narratives that make up (our) lives." Student tutors, who joined me for all the lectures and skills sessions and were thus fully aware of what was happening, were available to provide follow-up support and help for those in whom the exercises produced emotional trauma.

In order to fulfil the academic objectives in respect of HIV/AIDS, and to ensure that students were targeted as a client/consumer group, the class of 108 students was divided into twelve groups. Each group was allocated key questions that together covered all aspects of HIV/AIDS from the micro to the macro level, including the global. Students researched, discussed and presented their findings to the class. Saddington (1989) argued that some of the key role differences, within such a teaching paradigm, are to be found in the educator being a facilitator, a resource person, a catalyst and a negotiator rather than an expert, an instructor and a transmitter of knowledge. While the educator does not have to play the role of expert, it is vital that the educator possesses "expert" knowledge to add information, to correct misinformation and misperceptions where necessary, and to actively engage students in the processes of communicative action and argumentation, as described by Habermas (1996). The process has to shift from being educator-centred to being learner-centred. The class was involved in several interesting debates and discussion on sexuality and condom use, virginity testing, cultural factors in the transmission of HIV/AIDS, myths about HIV/AIDS, the impact of gender, the relationship between poverty, race and HIV/AIDS, the ethics of the South African government's response to the HIV/AIDS crisis in South Africa, and the roles 
of multinational drug companies in making anti-retroviral treatment accessible to people in the developing world.

One student wrote during the mid-term evaluation: "I enjoy the discussions, our lecturer is always trying to spark up a debate, which is nice ... I love the way some topics just spark up debate." A guest lecturer from the Treatment Action Campaign (TAC) was invited to talk to the students about their advocacy and lobby campaigns against the South African government for access to anti-retroviral treatment. Apart from the academic and political uses of such information, students were also exposed to the non-violent protest and advocacy initiatives of the TAC. An HIV+ person also addressed the students about her experience of being HIV+ and allowed for questions and discussion. As some students expressed anger and concern that HIV/AIDS was predominantly seen to be a Black problem, a White person was invited to speak. This served to break the myth that HIV/AIDS was a "black problem", and emphasised that all groups of people were vulnerable to infection. According to a report of the Human Sciences Research Council (cited in Daily News 5/12/2002), the HIV/AIDS prevalence rate by race was as follows: African 18.4\%; Whites, 6.2\%; Coloureds, $6.6 \%$ and Indians, $1.8 \%$. However, we discussed the high-risk factors such as poverty, geographic location, lack of access to resources and the more entrenched systems of patriarchy that did place Black people, especially women, at greater risk. In the 15 to 49 year age category, $17.7 \%$ of women were found to be HIV+ compared with $12.8 \%$ of men who were HIV+ (HSRC, cited in Daily News 5/12/2002). Identifying global, national and provincial patterns of HIV/AIDS was also used to draw relationships between race, socio-economic class, levels of social cohesion and inequality, and HIV/AIDS (see Sewpaul, 2003). The class was also shown a video reflecting both the reality of dying from AIDS and living positively with HIV. It was indeed interesting to note the changes in the views of students.

Some students initially expressed the view that that there were other more urgent priorities that the money could be used for in the country, and that we should focus our efforts on prevention rather than treatment of HIV+ persons, reflecting official government policy. They also reflected judgmental views differentiating between "innocent and guilty victims" and expressed the view that contracting HIV+ from sex was a choice. Thus the government had no ethical obligation to ensure universal access to treatment. However, as they worked on their exercises, engaged in the class debates, did the research for the assignment, followed the debates around the Constitutional Court hearings, and heard the HIV+ person, they began to open themselves to new ways of seeing and knowing. The class discussions and presentations, the questions posed by me and the guest lecturers and the students' enquiries reflected the power of argumentation and "discourse ethics" as described by Habermas (1996).

Discourse ethics, according to Berleur and Brunnstein (1997:246), "theorizes the way the 'lifeworld' ... of individuals may become the source of common and consensual action, being morally founded. Argumentative procedures may be established which provide the living actors with the capacity to overcome their own particular interests and define common norms about the way to live and act together." The experiences also served to confirm Gramsci's (1971) claim regarding the role of the intellectual in respect of transforming common sense, which functions without the benefit of critical interrogation, into good sense, that is practical, empirical common sense. According to Habermas (1996:4), the theory of communicative action, which embraces discourse ethics, "is expressed in a decentred complex of pervasive, transcendentally enabling structural conditions, but it is not a subjective capacity that would tell actors what they ought to do" (emphasis in the original). Communicative action and discourse ethics are specifically directed toward approximation of the "ideal conditions of a speech situation specifically immunized against repression and inequality. In this speech situation, persons for or against a problematic validity 
claim thematize the claim and, relieved of the pressures of action and experience, adopt a hypothetical attitude in order to test with reasons, and reasons alone, whether the proponent's claim stands up" (Habermas, 1996:228). The idea is to win the assent of participants in a noncoercive and non-distorting, but regulated, manner for the better judgements based on the best possible information and reasons, while integrating the perspectives of the participants' worldview and self-understanding. According to Habermas (1996:228), "As the reflexive form of communicative action, argumentation distinguishes itself socio-ontologically, one might say, by a complete reversibility of participant perspectives that unleashes the higher-level intersubjectivity of the deliberating collectivity."

The idea of the "ideal speech situation" in discourse provides the moral-practical foundations for critical theory. According to McCarthy (1981:307), "the requirements of the ideal speech situation, in which discourse can lead to genuine consensus, include communication-theoretic conceptualizations of the traditional ideas of freedom and justice: 'the truth of statements is linked in the last analysis to the intention of the good and true life." McCarthy (1981) argued that it is important to distinguish consensus arrived at through rational argument from that arrived at merely through matter-of-fact agreement. The evidence and arguments must be well grounded and rationally motivated, based on the peculiarly unforced force of the better argument that "moves" participants to accept affirmative positions (Habermas, 1996:227). All constitutive elements of the argument must be subject to critical examination.

The majority of students produced very considered and detailed term papers, reflecting a degree of maturity that is generally uncommon amongst first-year students. One student in an initial evaluation, early on in the course, wrote: "I was shocked to know that as first-year students we had to write 12 to 15 pages for the assignment. I don't think it's fair. That should be for third- or fourth-year students." However, once they got started the students certainly had a lot to say, with the majority writing between 20 to 30 pages; one student submitted an assignment of 46 pages! Of particular salience was the immediate impact that the work had on some students. One student wrote in her mid-term evaluation:

The course is extremely informative. I thought I knew everything I had to know about HIV/AIDS, but the course certainly proved me wrong! The course is a mixture of aspects dealing with culture, religion and global aspects and this makes it all the more interesting. It has never been boring to me. Without a doubt, every day I go home and present some new type of information.

At the end of her assignment a student wrote:

During the research I thought that in order to totally understand people living with the virus I must try and bring myself as close as possible to the reality of having the virus, so I went for the test. It was a frightening experience because after answering a questionnaire I realized that I was at high risk of obtaining (sic) the virus. I have learnt a lot from this assignment and if you're wondering, I am positively negative!!!

HIV/AIDS, like many other issues, raised the complex relationship between race, class and gender, which was one of the most pervasive themes of the lectures and practice sessions.

\section{Race, class and gender: Challenges in the South African context}

Applying Habermas's (1996) theory of communicative action and argumentation to the complex issues of race, class and gender proved far more difficult than dealing with HIV/AIDS. One of the most contentious issues discussed in class was the intersection between race, class and gender and 
their influence on access to power, status, privilege and resources. In the effort to get students to understand and apply the socio-structural concepts of social differentiation and social stratification (Berger, McBreen \& Rifkin, 1996), students were asked to identify the racial and gender stratification system dominant in South African society. The hierarchy was visually represented as a ladder on the board. There was no disagreement about Black females being at the bottom of the hierarchy, manifesting the highest degree of poverty and least access to status, resources and power. Some students claimed that White males were at the top of the hierarchy but this drew vehement denials, especially from White students, who asserted that it was the Black male who was now at the top. Data were presented from the Human Development Index with regard to poverty and educational levels to prove that White males were still at the top of the stratification system. The Human Development Index, which combines measures of life expectancy at birth, education and standards of living, reflects a distinctive hierarchy with Whites at the top, Indians and Coloureds in the middle and Blacks at the bottom of the hierarchy: $61 \%$ of Africans and $28 \%$ of Coloureds are poor, compared with 5\% Indians and 1\% Whites. Poverty is also not genderneutral. The poverty rate among female-headed households is $60 \%$, compared with $31 \%$ for maleheaded households (May, 1998). One White student, on being presented with the evidence, argued that would be so on account of the demographic profile, with Blacks being in the majority in South Africa. (Statistics South Africa estimated the country's population for the year 2002 to be over 43 million, of which about $77 \%$ are African, $10.5 \%$ White, $9 \%$ Coloured and $2.5 \%$ Indian/Asian). A Black student countered that this was the dominant pattern in other parts of the world, even where Blacks constituted ethnic minorities. Thus a lively discussion ensued on historical and universal representations and archetypes of race and gender!

I had to point out the difference between perception and reality, as supported by empirical data, in an attempt to deconstruct what some students had taken for granted about the world; this was characteristic of the entire course. While for the most part in the past, class unity among Blacks was presumed, this is increasingly not the case, with a rapidly emerging Black middle class in South Africa. While South Africa now has the highest Gini coefficient (0.65) in the world, the Gini coefficient within the Black population is almost as high as the national norm. Income inequality has become more consolidated over the past eight years. However, the quality of life for the majority of Black people has remained poor. An estimated $45 \%$ of the population is poor, almost all of whom are Black and live in either rural areas or urban slums/informal settlements (Department of Welfare and Population Development, 1998 - now Department of Social Development). South Africa is still a highly stratified society, with a close link between class and race. Terrablanche (2002:33) identified the following classes: a bourgeois elite consisting of $16.6 \%$ of the population (of which about $50 \%$ is White and about $50 \%$ black), receiving $72.2 \%$ of the total income; a petit bourgeois class consisting of $16.6 \%$ of the population (of which about $15 \%$ are white) receiving 17.2 of total income; and a lower class consisting of about $67 \%$ of the population (of which about $2 \%$ is white) receiving only about $10.6 \%$ of total income. One third of the approximately 15 million people in the two bourgeois classes are White, while only $2 \%$ of the about 30 million people in the lower class are White. Sixty percent of Africans are poor, compared to $1 \%$ of Whites (Terrablanche, 2002). The poverty of African people is highly visible in South Africa, but with a rapid and increasing level of inequality within the African population.

It appears that students who are or were advantaged and who do not actually see the poor confuse reality and perception and refuse to accept the still dominant racialised and gendered hierarchies in South Africa and how this influences access to status, power, privilege and access to resources. Popular Black TV personalities, black empowerment companies and Black MPs are erroneously seen to represent the majority of the Black people. An added complexity is the questioning of the ethics of redress and affirmative action by some Whites, Coloureds and Indians in South Africa 
(Sturgeon, 2002). Recent socio-political shifts appear to be challenging the identities of previously advantaged groups, who I find are reluctant to acknowledge the realities of the consequences of apartheid and their privileged historical and socio-economic positions. While critical reflection and debate may contribute to a reinterpretation of previously held beliefs, and to transformation of individual and collective consciousness, it can also be frightening, confusing and threatening. The following examples of students' comments reflect that the majority of students appreciated interrogation of such material:

The content is relevant and explores many issues that would normally not be talked about or even thought about. The 'snowball' effects of problems are also explored in great detail.

Even though I will be involved in the field of law, this course has most definitely met and surpassed my expectations. It has also expanded my knowledge of human behaviour as well as 'cleared up' many misconceptions. The course informs and helps people to deal with huge amounts of diversity in South Africa. Prejudice and discrimination could be understood and (maybe) controlled once people learn about human behaviour. Tolerance and respect are important.

The lecturer is not biased and lectures us from different perspectives. I misunderstood or took for granted many things, but the lecturer makes us understand by giving important and key information.

It is so interesting because it is so relevant to everyday life. It is such an eye-opening course and I have learnt so much about other South Africans from the speakers and lectures, and I have learnt some things about myself that I didn't understand.

While the above represented the views of the majority of students, the issues dealt with in class did cause discomfort among some, especially White students, as can be seen from the following:

I do feel that parts of the course tend to be racially prejudiced and we focus far too much on racial issues.

We discuss a lot of current issues in S.A. although I do feel that some topics are overemphasised e.g. racism.

Some things are best left in the closet!

Using non-traditional and flexible methods of teaching means that there might be unintended and potentially damaging consequences as discussed in the following section.

\section{And things go wrong! ... Some consequences of flexible teaching}

Once when discussing the gendered roles of men and women, and the stereotypical characteristics of masculinity and femininity, one White student argued very strongly that this was no longer so. While I acknowledged that we should not adopt an essentialist view of masculinity and femininity, and that there have been changes in gender roles over time, I emphasised that we should not allow ourselves to believe that some of our privileged positions are representative of the positions of all women. Lindiwe, a blind student, reminded the class that she was a victim of gender-based violence. Lindiwe, who gave her personal testimony to the class earlier on, described how she became blind when her boyfriend shot her because she wanted to terminate the relationship, such was his sense of ownership over her. She was in the final year of a nursing degree when she was shot and had to change career on account of her blindness. On noticing that students avoided Lindiwe and did not know how to respond to her on account of her blindness, I asked Lindiwe if she was prepared to address the class. She willingly agreed, presented her testimony, answered 
questions, gave students permission to relate to her as they related to other sighted students. Lindiwe later reported that it had made a positive difference in the interactions with the class. She also thought it was a therapeutic and affirming experience. Lindiwe was lauded for her strength and courage and was told by some students that she served as a positive role model for them. (Lindiwe's permission was secured to present her story here).

We raised issues of domestic violence, rape, and sexual abuse on a global level and the practice of honour killing and pre-natal sex selection (favouring males) in some contexts. I cited, as an example of atrocities against women, the case of Amina Lawal, who was sentenced to death by stoning in Northern Nigeria under Sharia law. On students asking what Sharia law was, a Muslim student said that it was Islamic law. This student, who was quite upset, came to me immediately after the lecture indicating that some of the White students sitting behind her were swearing under their breath about "these fucking Muslims and their stupid law." I realised then that neither the student nor I had taken the time to explain that Sharia law, as applied in Northern Nigeria, reflected fundamentalist views of Islam. We failed to clarify that it was not characteristic of all of Islam and that the element of compassion, which is a central feature of Islam, was lacking in the application of the law.

I discussed with the student how we might undo the negative message and the possible inadvertent reinforcement of Islamophobia in the class. She offered to bring to class a moulana (a Muslim priest) to speak about Islam and to clarify the meaning and application of Sharia law. The moulana, a young man, did turn up to class, but with each claim that he made - to my sheer disappointment and to the horror of the students - he reinforced every negative stereotype of women and totally condoned Sharia law as applied in Northern Nigeria! He made such claims as: "When it comes to an issue such as theft, we talk about the 'man and the woman' as a man is more likely to initiate a crime such as this. However, when it comes to a sexual crime or adultery we talk about the 'woman and the man'", claiming that the woman was the gatekeeper of men's sexuality and that it was the duty of the woman to prevent sexual contact from taking place.

The murmurs of dissent from the class were obvious as he was talking, and they challenged him very directly on his expressed views after his presentation. I felt indebted to a vociferous class for saving me the embarrassment of confronting an invited guest lecturer! I had to spend some time in subsequent lectures trying to undo the further negative image about Islam with which he had left the class. However, he did serve to strengthen the argument that in some contexts women are indeed expected to conform to narrow traditional and patriarchal definitions of womanhood and femininity, with their roles and worth, and their subsequent treatment, being circumscribed by such definitions. Hopefully, this helped the more advantaged and emancipated students in class understand that they did not represent women on a universal level. This experience supported Giroux's (1997) call for discourses that provide dominant groups with the knowledge to examine, acknowledge and unlearn their own privileged positions.

\section{CONCLUSION}

In this paper I have elucidated the importance of emancipatory citizenship education to social work education and training, identified the objectives and underlying epistemologies of the Human Behaviour and Social Environment course, and emphasised the importance of negotiating relationships for the creation of a participatory and emancipatory approach to education. I have also reflected the application of Habermas's (1996) theory of communicative action and discourse ethics to complex issues including HIV/AIDS and the relationship between race, class and gender in the South African context, and highlighted a potentially damaging, unintended consequence of such teaching strategies. Part Two of the article focuses specifically on the integration of theory 
and practice through the use of creative teaching and learning strategies. Part Two describes students' demonstrations of how the biological, psychological, socio-structural and cultural dimensions apply to the phases of conception, birth and infancy; early childhood; late childhood; adolescence; adulthood; old age and death. Some of the challenges in the use of experiential and emancipatory educational strategies, and in the use of Habermas's theory of communicative action and discourse ethics are discussed in Part Two of this paper.

\section{REFERENCES}

AITCHISON, J. \& GRAHAM, P. 1989. Potato crisp pedagogy. In: CRITICOS, C. (ed) Experiential learning in formal and non-formal education. Durban: University of Natal, Media Resource Centre.

BERGER, R.; McBREEN, J.T. \& RIFKIN, M.J. 1996. Human behaviour: a perspective for the helping professions. New York: Longman.

BERNSTEIN, A. \& GRAY, M. 1989. Working together: An experiential programme dealing with cross-cultural awareness. In: CRITICOS, C. (ed) Experiential learning in formal and nonformal education. Durban: University of Natal, Media Resource Centre.

BERLEUR, J. \& BRUNNSTEIN, K. 1997. Ethics of computing: codes, spaces for discussion and law. London: Chapman \& Hill.

DEPARTMENT OF WELFARE AND POPULATION DEVELOPMENT 1998. White paper on population policy. Pretoria: Government Printers.

DOMINELLI, L. 1996. The future of social work education: Beyond the state of the art. Scandavanian Journal of Social Welfare, 5:194-201.

DOMINELLI, L. 2002. Feminist social work theory and practice. New York: Palgrave.

EDWARDS, J. \& FOLEGMAN, K. 1993. Developing citizenship in the curriculum. London: David Fulton Publishers.

FREIRE, P. 1970. The pedagogy of the oppressed. Harmondsworth: Penguin Books.

FREIRE, P. 1972. Cultural action for freedom. Harmondsworth: Penguin Books.

FREIRE, P. 1973. Education for critical consciousness. New York: The Seabury Press.

GIROUX, H.A. 1983. Theory and resistance in education: A pedagogy for the opposition. London: Heinemann Educational Books.

GIROUX, H.A. 1994. Living dangerously: Identity politics and the new cultural racism. In: GIROUX, H.A. \& McLAREN, P. (eds) Between borders: Pedagogy and the politics of cultural studies. New York: Routledge.

GIROUX, H.A. 1997. Pedagogy and the politics of hope: Theory, culture and schooling. Colorado: Westview Press.

GRAMSCI, A. 1988. Gramsci's prison letters. (transl by HENDERSON, H.) Edinburgh: Zwan Publications.

Gramsci, A. 1971. Selections from the prison notebooks. (ed and transl by HOARE, A. \& SMITH, G.N.) London: Lawrence and Wishart. 
GRAMSCI, A. 1977. Selections from political writings 1910-1920. London: Lawrence and Wishart.

HABERMAS, J. 1996. Between facts and norms: Contributions to a discourse theory of law and democracy. Cambridge, The MIT Press.

Heywood, A. 1999). Political theory: An introduction. London, MacMillan Press Ltd.

LOUW, E. \& ANNECKE, W. 1989. Beyond race: The 'class gap' between educationalists and deprived students in South Africa. In: CRITICOS, C. (ed) Experiential learning in formal and non-formal education. University of Natal, Durban: Media Resource Centre.

LYNCH, J. 1992. Education for citizenship in a multicultural society. New York: Cassell.

McCARTHY, T. 1981. The critical theory of Jurgen Habermas. Cambridge: The MIT Press.

Robinson, M. and Angelis, D. 1989. Transforming teaching and learning: Easier said than done. In CRITICOS, C. (ed) Experiential learning in formal and non-formal education. Durban: University of Natal, Media Resource Centre.

SADDINGTON, T. 1989. Learner responsibility: Sharing the curriculum in a formal setting. In: CRITICOS, C. (ed) Experiential learning in formal and non-formal education. Durban: University of Natal, Media Resource Centre.

SEWPAUL, V. 1994. The position of black women in South African society: A feminist perspective. Social Work/Maatskaplike Werk, 30(4): 346-354.

SEWPAUL1, V. 2003. Reframing epistemologies and practice through international exchanges: Global and local discourses in the development of critical consciousness. In: DOMINELLI, L. and BARNARD, W. T. (eds) Broadening horizons: international exchanges in social work. Aldershot: Ashgate.

SEWPAUL, V. \& JONES, D. (2004 - in press). Global Standards in Social Work Education and Training. To be published in Journal of Social Work Education in 2004.

STURGEON, S. 2002. Developing cultural awareness in human service professionals: A personal journey. Social Work/Maatskaplike Werk, 38(2):173-181.

TERRABLANCHE, S. 2002. A history of inequality in South Africa 1652-2002. Pietermaritzburg: University of Natal Press. 